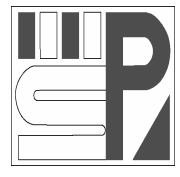

Science Press
Journal of Arid Land

2012, 4(3): 251-259

doi: 10.3724/SP.J.1227.2012.00251

jal.xjegi.com; www.chinasciencejournal.com

\title{
The effect of total carbon on microscopic soil properties and implications for crop production
}

\author{
Inma LEBRON ${ }^{1}$, Milton Earl MCGIFFEN $\mathrm{Jr}^{2 *}$, Donald Louis SUAREZ ${ }^{3}$ \\ ${ }^{1}$ Centre for Ecology and Hydrology, Bangor, Gwynedd, LL57 2UW, UK; \\ ${ }^{2}$ Department of Botany and Plant Science, University of California, Riverside, CA 92521-0334, USA; \\ ${ }^{3}$ U.S. Salinity Laboratory, Riverside, CA 92521-0334, USA
}

\begin{abstract}
Soil structure is a dynamic property affected by physical, chemical, and microbiological processes. Addition of organic matter to soils and the use of different management practices have been reported to impact soil structure and crop production. Moderation in soil temperature and increases in microbial activity and soil water retention are often suggested as reasons for the rise in crop yield when organic matter is added to the soil. Less is known about the direct effect of changes in soil structure on crop production. A field experiment was conducted to study the effect of summer cover crop and in-season management system on soil structure. The experiment was a nested design with summer cover crop as the main plot and management system as the subplot. Summer cover crop treatments included cowpea (Vigna unguiculata L. Walp.) incorporated into the soil in the fall $(\mathrm{Cl})$, cowpea used as mulch in the fall (CM), sudangrass (Sorghum vulgare) incorporated into the soil in the fall (S), and dry fallow or bare ground (B). Management systems were organic (ORG) and conventional (CNV) systems. Lettuce (Lactuca sativa L.) and cantaloupes (Cucumis melo L.) were cultivated in rotation in the plots for three consecutive years using the same cover crops and management systems for each plot. Disturbed and undisturbed soil cores were collected at the end of the third year and used for laboratory experiments to measure physical, chemical, and hydraulic properties. Image analysis was used to quantify soil structure properties using a scanning electron microscope on thin sections prepared from the undisturbed soil cores. We found that total soil carbon was correlated with porosity, saturation percentage, and pore roughness. Pore roughness was correlated with crop production in general and with marketable production in particular. We found that the higher the complexity of the pore space, the more water retained in the soil, which may increase soil water residence and reduce plant water stress.
\end{abstract}

Keywords: summer cover crop; management systems; soil structure properties; total carbon

Organic matter content is considered a major factor affecting soil structure, especially in arid environments and sandy soils where organic matter is often numerically low $(<1 \%)$ but nonetheless very critical. A positive correlation between organic matter content and aggregate stability in many soil types and management systems has been reported (Kemper and Koch, 1966; Tisdall and Oades, 1982; Chaney and Swift, 1984; Bartoli et al., 1988). Increasing soil organic matter increases the ability of the soil to supply water, air, and nutrients to growing plants. The use of cover crops, incorporation of plant residues, addition of manure, and decreased intensity of tillage can all increase soil organic matter content. In addition to organic matter buildup, changing crop management practices can lead to a cascade of changes in the physical, chemical and biological properties of soil, including increased $\mathrm{pH}$, increased soil aeration, and increased soil microorganism activity (Parr and Willson, 1980; Macrae and Mehuys, 1987; Astier et al., 1994; Drinkwater et al., 1995; Roe, 1998; Cuevas et al., 2000; Magdoff and Van Es, 2000), all of which have important consequences for crop production (Hutchinson and McGiffen, 2000; Bronick and Lal, 2005; Wang et

Received 2012-01-27; accepted 2012-04-20

"Corresponding author: Milton Earl MCGIFFEN Jr (E-mail: milt@ucr.edu) 
al., 2008).

Incorporation of organic carbon into the soil fabric is a microbe-driven process affected by temperature, chemical environment, soil clay mineralization, and many other factors. The interactions among all those variables are not well understood. A critical question is what influence different sources of organic matter and management practices have in the long-term accumulation of carbon in soils. For example, it has been suggested that the nature of soil organic matter changes with aggregate size (Oades, 1984, 1989).

The first step in the retention of soil carbon occurs when plant-derived organic substances are degraded and transformed by bacteria and fungi into sugars, humic and fulvic acids, and a variety of other organic substances that accumulate on the surface of soil particles. These soil-organic matter complexes are then cemented together into micro-aggregates $(<250 \mu \mathrm{m})$ by biopolymers (more persistent organic matter), which are further knitted together into macro-aggregates by root hairs and fungi (fresh, readily degradable organic matter). Several authors have shown that macro-aggregates have greater microbial biomass (Gupta and Germida, 1988) and particulate organic matter (Cambardella and Elliot, 1993), contain a more labile organic fraction (Elliot, 1986), and more C and $\mathrm{N}$ than micro-aggregates (Tisdall and Oades, 1982).

In a feedback process, soil structure controls microbial activity, biodiversity, and the size of the soil biomass pool. Bacteria and fungi organize spatially in relation to redox, oxygen, and chemical gradients. These chemical gradients are located in the pore space within and among aggregates. Pore space and shape are critical in the water retention of a soil. Soils with higher clay or higher organic matter content typically have higher water retention capacity due partially to a more complex geometry in the pore space (Gaillard et al., 1999). Higher water retention is particularly beneficial to crops when the availability of water is critical, e.g. in arid climates.

Soil structural changes induced by microbial transformations of organic substrates occur mainly at the microscopic level (Dorioz et al., 1993). Electron microscopy (EM) techniques have been used to describe the different types of clay-polysaccharide associations and the production of microstructures with specific physical properties (Chenu, 1993; Laird, 2001). Additionally, EM/image analysis has quantified the pore space and geometry of soils as soil chemical properties change (Lebron et al., 1999). However, there are no studies that quantify the in situ changes in aggregate size and pore space distribution after three years of continuous addition of organic matter to agricultural soils.

The interactions between organic carbon, soil structure, availability of water, and soil production are very complex, and our understanding of their underlying mechanisms is incomplete. To improve and sustain crop productivity we need to understand how carbon is transformed and incorporated in the soil, the role that carbon has in soil structure, and the impact that changes in soil structure have in crop production in general. But most importantly, we must determine the soil structural characteristics that affect crops. We sampled soil from a multi-year field study and then used scanning EM (SEM) and image analysis to examine how long-term $\mathrm{C}$ accumulation affects soil structure and the relationship of soil structural parameters with crop productivity. The irrigated desert soil in our study provided a unique opportunity to measure the effect of adding different forms of organic matter to a low organic matter soil in a hot climate.

\section{Materials and methods}

A long-term experiment on cover crops, tillage, and management systems was conducted to provide data across a broad range of management systems. Plots were continuously maintained in the same field from 1998 to 2004 at the University of California Coachella Valley Agricultural Research Station in Thermal, CA. The Coachella Valley is located in the Lower Colorado River Desert in Southern California with an elevation of around sea level and a wide diversity of crops. The soil at the research site is a Coachella sandy loam (coarse-silty, mixed, calcareous, hyperthermic Typic Torrifluvent). Mean daily temperature during the winter growing season varies from $11^{\circ} \mathrm{C}$ to $23^{\circ} \mathrm{C}$ (Wang et al., 2008).

The experiment was factorial, arranged in a split-plot design. The main-plot factor was summer cover crop type and the subplot factor was management system. Cover crop treatments included (i) sum- 
mer cowpea incorporated into the soil in the fall (CI), (ii) summer cowpea used as surface mulch in the fall (CM) with minimum tillage, (iii) summer sudangrass incorporated into the soil in the fall (S), and (iv) summer dry fallow or bare ground (BG). Management systems included organic (ORG) and conventional (CNV) ones. Both main-plots and subplot treatments were assigned using a complete block randomization. Each replicate included six beds spaced $1.5 \mathrm{~m}$ apart, center-to-center, each bed $6 \mathrm{~m}$ in length.

Synthetic fertilizer (15:15:15; NPK) was used in the CNV system and 50:50 composted yard waste and chicken manure was used in the ORG. For insect control, a formulation of Bacillus thuringiensis subsp. aizawai (XenTari) was used in the ORG plots, and bifenthrin (Capture) was used in the CNV plots. $B a$ cillus thuringiensis is a biocontrol insecticide approved by California Certified Organic Farmers (CCOF) for use in lettuce. Insect treatment was initiated only when a threshold of 2 insects per ten plants was reached. In the CNV system, there was a pre-established schedule of four insecticide applications for both the lettuce and the melon crops. In all treatments weeds were controlled manually.

Cover crops were planted in July and incorporated into soil in September, except for the cowpea mulch treatment, which was mulched and distributed on the top of the soil without tillage. Lettuce variety 'Shining Star' seedlings were transplanted by hand on $1.5-\mathrm{m}$ wide beds in October. Final density was 45,000 plants per hectare, with two rows per bed. Prior to planting, beds were wet to field capacity by sprinklers and plants were drip irrigated immediately after transplanting. Lettuce was harvested in December. The small or damaged heads were classified as unmarketable and separated from the marketable heads, and then marketable and unmarketable heads were weighed separately.

Lettuce was followed in the rotation by cantaloupe (Cucumis melo L.) variety 'Magellan'. The melons were transplanted in single-row, $1.5-\mathrm{m}$ wide beds and a final density of 7,500 plants per hectare. Melon was transplanted in March and harvested in June. Over-mature, small or damaged fruits were considered non-marketable and separated from the marketable fruit prior to weighing.

All treatments (cover crop and management system) were kept in the same location throughout the duration of the experiment using permanent marks. This was mainly to enhance the effect of different systems and simulate the buildup of effects that may occur when growers follow the same practice each year, e.g. during the three-year transition period required before it can be certified as "organic" (McGiffen, 2011). Soil samples were collected for electron microscopy following the third-year melon harvest in July 2001. As preparation of thin sections is prohibitively laborious, the number of replicate plots sampled was limited to two from each of the eight treatments. A total of sixteen undisturbed and sixteen disturbed soil samples were collected and used to examine the correlation between total soil carbon and soil microscopic properties. A larger number of replicates was later sampled and used in an analysis of variance of cropping system effects on soil and crop nutrient status and yield (Wang et al., 2008).

A portion of the disturbed samples were analyzed for the chemical composition of the saturation extract (U.S. Salinity Laboratory Staff, 1954; Rhoades, 1982). The cation composition of each soil extract was analyzed by inductively coupled plasma emission spectroscopy. The remaining portion of the disturbed soil samples was analyzed for total carbon content (TOC) and particle size distribution. TOC was determined in the soil by dry combustion coupled with coulometry and inorganic carbon by acid addition (UIC Corp., Joliet, IL.). Particle size distribution was measured following the methodology described in Gee and Bauder (1986).

Undisturbed soil cores $12 \mathrm{~cm}$ in diameter and $12 \mathrm{~cm}$ in height were collected from the top $25 \mathrm{~cm}$ of the soil profile from the same plots as the disturbed soil core. Saturated hydraulic conductivity $\left(\mathrm{K}_{\mathrm{sat}}\right)$ was measured on all soil cores using Colorado River water as eluent $\left(\mathrm{HCO}_{3}{ }^{-}=2.8, \mathrm{Cl}^{-}=3.1, \mathrm{SO}_{4}{ }^{2-}=5.8, \mathrm{Na}^{+}=5.0, \mathrm{~K}^{+}=0.12\right.$, $\mathrm{Ca}^{2+}=4.0, \quad \mathrm{Mg}^{2+}=2.5 \quad \mathrm{mmol} / \mathrm{L} ; \quad \mathrm{EC}=1.15 \quad \mathrm{dS} / \mathrm{m} ;$ $\mathrm{pH}=8.15, \mathrm{SAR}=2.8$ ). Samples were saturated by capillary rise from below to allow a gradual rise in water level until water ponded on the surface. The columns were allowed to equilibrate with the water overnight. 
Hydraulic conductivity $\left(\mathrm{K}_{\text {sat }}\right)$ was measured with the constant head method. Subsequently the soil was dried at room temperature; bulk density $\left(\Delta_{\mathrm{B}}\right)$ was measured; and then each undisturbed soil core was impregnated with an epoxy to prepare a thin section.

Thin sections were prepared by impregnation of the samples with epoxy EPO-TEK 301 (Epoxy Technology Inc., Billerica, MA). After hardening, a thin section $3.5 \mathrm{~cm} \times 2.5 \mathrm{~cm}$ was cut at the plane perpendicular to the water flow, mounted on a glass slide, and polished. Thin sections were observed under the SEM (AMRAY 3200, AMRAY Inc. Bedford, MA) with the backscatter electron detector. The intensity of the back scattered electrons (BE) is a function of the atomic weight of the element, with heavier elements having higher back scattering properties. The result is that elements with higher atomic weight give images that are brighter than lighter elements in the sample (Fig. 1). Charging effects were counteracted by using low-vacuum in the specimen chamber and by the introduction of air molecules to dissipate the charge accumulated on the surface of the sample. No coating of the sample is needed. The selection of the magnification was made with a two-point correlation function following the methodology described by Lebron et al. (1999).

The grey scale provided by the micrograph can be represented by a histogram with a bimodal distribution. The histogram is used to resolve pores from particles through the transformation of the grey color image into a binary image. The histograms for the soils in this study presented an unambiguous minimum value between the two modes of the histograms that we used as the threshold to separate the pores and the particles.

The quantification of the features in the micro-picture was performed using image analysis software (Princeton Gamma-Tech Inc., Princeton, NJ). After the binary image is obtained, the program counts the pixels that constitute each of the features; i.e. the bright pixels are the aggregates and the dark are the pores. Since our detection limit was established to be $7 \mu \mathrm{m}$, we considered that all the bright features already constitute an aggregate.

Area (A) of aggregates, total porosity, and pore roughness (R, expressed as $\left.\mathrm{P} /\left(\pi \cdot \mathrm{D}_{\text {avg }}\right)\right)$ were directly

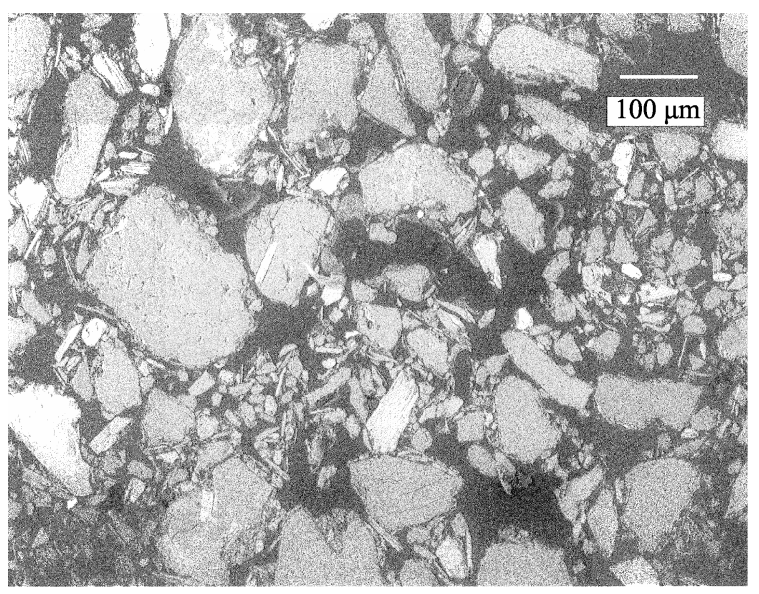

Fig. 1 Micrograph of a thin section of one of the undisturbed soil samples

measured in the micrographs using the same image analysis. Each one of the black features (pores) in Fig. 1 was quantified as well as the bright features (aggregates). To increase the size of the sampling area, we collected 10 pictures from each thin section distributed in a regular grid; the total area sampled is equivalent to $2.5 \mathrm{~mm}^{2}$. Each of the pictures was processed and accumulated in one file per sample, and a total of 20,000 to 40,000 pores and aggregates per sample were quantified.

Since the microscopic parameters (e.g. aggregate size distribution) were not normally distributed, we performed a Spearman rank correlation to relate physical, chemical, microscopic, and crop yield for the soils studied (Table 1).

\section{Results and discussion}

\subsection{Soil physical properties as affected by total carbon content}

After three years of continuous addition of organic matter, the percentages of organic carbon in the samples were slightly more than the original $0.5 \%-0.7 \%$ (Table 1). Several aspects of the soil's structure and location may explain the low sequestration of carbon. There is evidence in the literature that the turnover of $\mathrm{C}$ and $\mathrm{N}$ is faster in coarse-textured soils than in fine-textured soils (van Veen et al., 1984; Merckx et al., 1985; Rutherford and Juma, 1992; Juma, 1993). Soil organic carbon content is correlated not only with the amount of colloidal particles present, but also with 
Table 1 Spearman rank correlation matrix for soil parameters

\begin{tabular}{|c|c|c|c|c|c|c|c|c|c|c|c|c|c|c|}
\hline & $\mathrm{S}+\mathrm{c}$ & SP & $\mathrm{BD}$ & $\% \mathrm{C}$ & SEM & $\mathrm{pH}$ & $\mathrm{EC}$ & Aa & $\mathrm{Rp}$ & $\mathrm{K}_{\mathrm{sat}}$ & $\begin{array}{l}\text { Lettuce } \\
\left(\mathrm{t} / \mathrm{m}^{2}\right)\end{array}$ & $\begin{array}{l}\text { hw } \\
(\mathrm{g})\end{array}$ & $\begin{array}{l}\text { Melon } \\
\left(\mathrm{t} / \mathrm{m}^{2}\right)\end{array}$ & $\begin{array}{c}\text { Market } \\
\text { melons } \\
\left(\mathrm{t} / \mathrm{m}^{2}\right)\end{array}$ \\
\hline $\mathrm{S}+\mathrm{c}$ & 1 & & & & & & & & & & & & & \\
\hline SP & $0.69^{*}$ & 1 & & & & & & & & & & & & \\
\hline $\mathrm{BD}$ & $-0.53^{*}$ & -0.44 & 1 & & & & & & & & & & & \\
\hline$\% \mathrm{C}$ & $0.55^{*}$ & $0.85^{* *}$ & $-0.66^{*}$ & 1 & & & & & & & & & & \\
\hline SEM & 0.35 & 0.34 & $-0.84^{* *}$ & $0.58^{*}$ & 1 & & & & & & & & & \\
\hline $\mathrm{pH}$ & -0.01 & -0.08 & -0.11 & -0.18 & -0.34 & 1 & & & & & & & & \\
\hline $\mathrm{EC}$ & -0.33 & 0.00 & 0.00 & -0.07 & -0.08 & $-0.56^{*}$ & 1 & & & & & & & \\
\hline Aa & -0.14 & -0.01 & 0.25 & -0.23 & -0.39 & -0.19 & $0.74^{* *}$ & 1 & & & & & & \\
\hline $\mathrm{Rp}$ & $-0.56^{*}$ & $-0.68^{*}$ & 0.15 & $-0.59^{*}$ & -0.36 & -0.40 & $-0.51^{*}$ & $-0.65^{*}$ & 1 & & & & & \\
\hline $\mathrm{K}_{\mathrm{sat}}$ & -0.16 & 0.16 & $-0.53^{*}$ & 0.27 & $0.53^{*}$ & $-0.73^{* *}$ & 0.34 & -0.09 & $-0.68^{*}$ & 1 & & & & \\
\hline Lettuce $\left(\mathrm{t} / \mathrm{m}^{2}\right)$ & 0.09 & -0.09 & 0.31 & -0.35 & -0.30 & -0.09 & 0.39 & $0.73^{* *}$ & -0.34 & -0.35 & 1 & & & \\
\hline hw (g) & 0.42 & 0.38 & -0.31 & 0.19 & 0.11 & -0.40 & 0.26 & 0.29 & $-0.74^{* *}$ & 0.37 & 0.30 & 1 & & \\
\hline Melon ( $\left.\mathrm{t} / \mathrm{m}^{2}\right)$ & -0.05 & 0.00 & -0.28 & 0.22 & 0.32 & -0.33 & 0.06 & 0.05 & $-0.55^{*}$ & -0.01 & 0.06 & -0.29 & 1 & \\
\hline $\begin{array}{c}\text { Market melons } \\
\left(\mathrm{t} / \mathrm{m}^{2}\right)\end{array}$ & 0.22 & 0.48 & $-0.70^{* *}$ & $0.63^{*}$ & $0.53^{*}$ & -0.45 & 0.18 & -0.06 & $-0.51^{*}$ & 0.26 & -0.17 & -0.04 & $0.58^{*}$ & 1 \\
\hline
\end{tabular}

Note: Silt and clay $(\mathrm{S}+\mathrm{c})$, saturation percentage $(\mathrm{SP})$, bulk density $\left(\mathrm{BD}, \Delta_{\mathrm{B}}\right)$, total organic carbon $(\% \mathrm{C})$, porosity as measured by SEM (SEM), $\mathrm{pH}$, electrical conductivity $(\mathrm{EC})$, median area of aggregates $(\mathrm{Aa})$, pore roughness $(\mathrm{Rp})$, saturated hydraulic conductivity $\left(\mathrm{K}_{\text {sat }}\right)$, production of lettuce $\left(\mathrm{t} / \mathrm{m}^{2}\right)$, average lettuce head weight (hw, in $\left.\mathrm{g}\right)$, total melon yield in $\mathrm{t} / \mathrm{m}^{2}$, and marketable melon yield in $\mathrm{t} / \mathrm{m}^{2}$. ${ }^{*}$ and ${ }^{* *}$ mean significance at $P<0.05$ and $P<0.001$ level, respectively.

specific mineralogy. Laird (2001) maintains that humic substances are intimately associated with soil clay minerals and that mineralogy determines the chemical composition of the humic substances retained at the mineral surface. Laird (2001) defined three critical functions of soil clay minerals in the formation and stabilization of humic substances: accumulation of humic monomers by adsorption mechanisms, polymerization of those monomers, and sequestration of the humic substances formed making them unavailable to soil microorganisms. The low clay content of these soils restricted the stabilization, accumulation, and sequestration of organic substance, which led to the observed low organic matter content.

The variability in the size distribution of particles $<$ $50 \mu \mathrm{m}$ in our plots is very similar to the variability of the total carbon among the samples (40\%). We found correlation at $P=0.001$ level between total $\mathrm{C}$ and \% silt+clay (Table 1, Fig. 2). The content of inorganic carbon, most likely in the form of $\mathrm{CaCO}_{3}$, also increased when the colloidal particle content increased. $\mathrm{CaCO}_{3}$ is a well-known cementing agent in soils, which keeps particles together to form the building blocks of soil structure. Lebron et al. (1999) used SEM and EDX techniques and observed $\mathrm{CaCO}_{3}$ pre- cipitates in the interlayer of the clay aggregates; the precipitates are probably generated as the soil dries and the soil solution becomes calcite supersaturated. Both organic matter and calcite increase the aggregate stability of the soil and improve the soil structure as well as increase water-retention properties and aeration (Kemper and Koch, 1966; Tisdall and Oades, 1982; Oades, 1984, 1987, 1993). It has been indicated in several studies that not only the total organic carbon but specific organic molecules derived from the transformation during the mineralization process is what provides the necessary binding among the soil particles to generate micro-aggregates. Young and Ritz (1999) found that the quality of organic matter plays an important role in mediating the presence and functioning of microorganisms. These microorganisms are the vehicles to make micronutrients available to plants. The quality of the organic residue, the physico-chemical environment, and the type of organism in the decomposer community condition this availability (Gregorich and Janzen, 2000).

Saturation percentage (SP) is the amount of water required to prepare a paste of the soil at saturation; i.e. the higher the SP, the greater the water retention ability of a soil. Figure 3 shows that as total $\mathrm{C}$ increased 


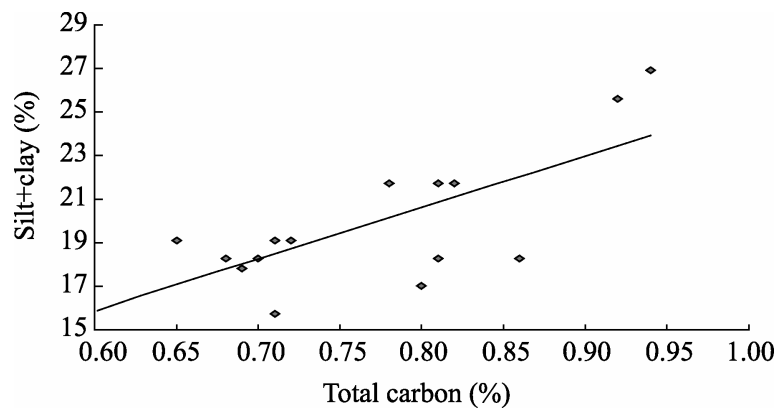

Fig. 2 Silt plus clay content versus the total carbon of the 16 soil samples from Coachella Valley Agricultural Research Station

the water retention properties of the soils increased, and more water was retained by the soil at saturation. This correlation may be crucial for the relationship among retention of water films in the soil, microorganism activity, and micronutrient availability to plants.

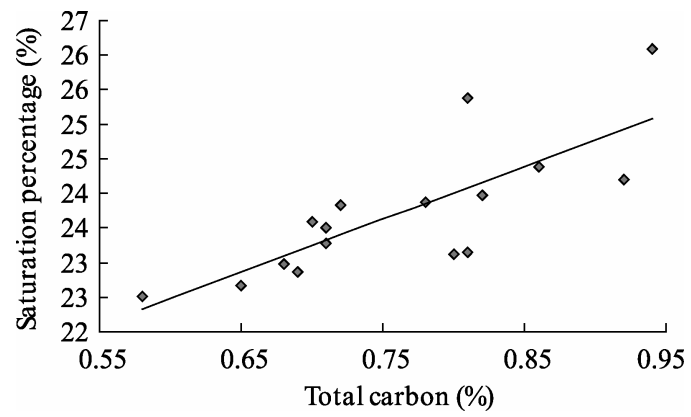

Fig. 3 Saturation percentage as a function of total carbon for the 16 soil samples from Coachella Valley Agricultural Research Station

The bulk density $\left(\Delta_{\mathrm{B}}\right)$ of the soil cores was correlated with both the $<50 \mu \mathrm{m}$ particles and the $\% \mathrm{C}$, with a slightly higher $R^{2}$ for $\% \mathrm{C}$ (Table 1). As \%C increased, $\Delta_{\mathrm{B}}$ decreased; i.e. the soil was less compacted when the $\% \mathrm{C}$ increased (Fig. 4). Total porosity was highly correlated with $\Delta_{\mathrm{B}}$, as expected, and with $\% \mathrm{C}$ (Table 1).

Since SP, $\Delta_{\mathrm{B}}$, and $\% \mathrm{C}$ are all highly correlated with silt and clay contents, we adjusted the correlation to eliminate possible induced correlation (SAS Institute Inc., 1988). The $R^{2}$ for the adjusted correlation between $\mathrm{SP}$ and $\% \mathrm{C}$ is 0.75 and between $\Delta_{\mathrm{B}}$ and $\% \mathrm{C}$ -0.52 . The $R^{2}$ for the adjusted correlation between $\Delta_{\mathrm{B}}$ and total porosity is -0.79 .

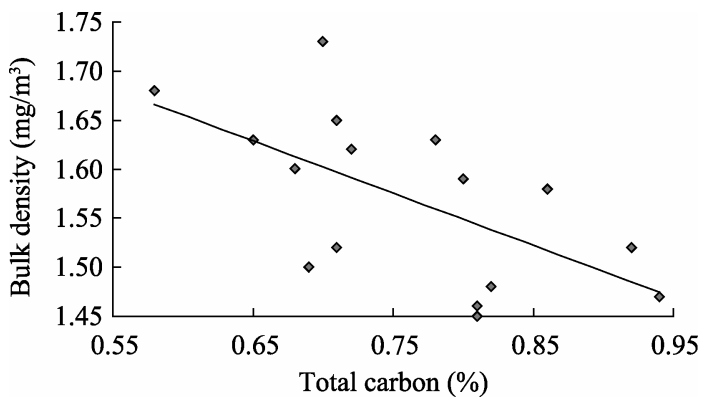

Fig. 4 Bulk density as a function of total carbon for the 16 soil samples from Coachella Valley Agricultural Research Station

\subsection{Soil microstructure as affected by soil chemi- cal parameters and total carbon}

Electrical conductivity (EC) and SAR (Sodium absorption ratio) are not independent variables for our soils, but are correlated at the 0.05 level (data not shown). This dependency implies that the effect of chemistry on soil structure must be evaluated as a combined interaction of the different aspects of the soil chemical composition. For example, EC increased at the same time as sodium increased (Table 1), but both parameters have the opposite effect on soil structure. This situation is very common in natural soils but means that we are not readily able to differentiate the effects that chemical variables have on soil structure. Soils with the same geological parent material and irrigated with water with the same chemical composition tend to build up salinity from the same salt source.

The low SAR and $\mathrm{pH}$ values indicate that the dominant determinant of soil stability in our study was the flocculant effect of the EC; i.e. the area of the aggregates was correlated with EC, with aggregate size increasing as EC increases (Table 1). Several studies reported that increases in the salt content of the soil solution reduced the thickness of the double layer of the soil particles, allowing the attractive forces to pull the particles together and form flocs (Goldberg and Forster, 1990; Lebron and Suarez, 1992; Hesterberg and Page, 1993; Kretzschsmar et al., 1993). The adjusted $R^{2}$ after eliminating the silt plus clay influence did not diminish $\left(R^{2}=0.75\right)$, indicating that for these particularly sandy soils the fine particles did not influence the aggregate size and EC was the main flocculation driver. 
Another important soil structural factor affecting water and solute transport is pore roughness. Pore roughness is sometimes used to express the tortuosity of the system and indicates the length of the path along which water and solutes travel when passing through the soil profile. Roughness was inversely correlated with $\mathrm{EC},<50 \mu \mathrm{m}$ particles, saturation percentage, $\% \mathrm{C}$, size of the aggregates, and $\mathrm{K}_{\text {sat }}$ (Table 1$)$. As $\mathrm{EC}$ and aggregate size increased, pore roughness decreased. When aggregates are larger, the pores are also larger, increasing the ability of the soil to hold and transport water.

The correlation of roughness with $\mathrm{K}_{\mathrm{sat}}$ is important and the implications vary depending on the type of irrigation used. Roughness is associated with the tortuosity of the path that the water has to go through during infiltration-the higher the tortuosity, the longer the path, which consequently lowers $\mathrm{K}_{\text {sat }}$. Lower $\mathrm{K}_{\text {sat }}$ may indicate anaerobic conditions during flood irrigation episodes. In the case of drip irrigation, low $\mathrm{K}_{\text {sat }}$ may result in the evaporation of irrigation water before plant roots have the opportunity to extract sufficient water. In both cases, the decrease in $\mathrm{K}_{\text {sat }}$ may have repercussions in crop production and should be taken into consideration when making management decisions.

\subsection{Crop production as affected by soil micro- structure and total carbon}

The importance of soil structure in crop production is based on the interaction between the water films present in the soil. These water films interact with the basic spatial architecture of the pore network and behave as valves that restrict the flow of oxygen and other gases in the pore network. These microenvironments have consequences for biological activity, organic transformation, and crop productivity (Young and Ritz, 1999). Many chemical elements are significantly affected by redox potential. Redox potential, together with ionic strength and $\mathrm{pH}$, determines the speciation of the soluble nutrients, which is critical for the availability of those elements to plants. Soil structure also impacts crop production by influencing root development, which ultimately affects plant anchorage, water and nutrient uptake, storage of carbohydrates, and synthesis of growth regulators (Juma, 1993).
Increased soil aggregate area was strongly correlated with higher total lettuce production (Fig. 5; Adjusted $R^{2}=0.76$ ). This may have been the result of greater plant available water as aggregate area increased. However, when lettuce production was evaluated in terms of the average weight of the heads, the pore roughness parameter was more significant than aggregate area (Table 1).

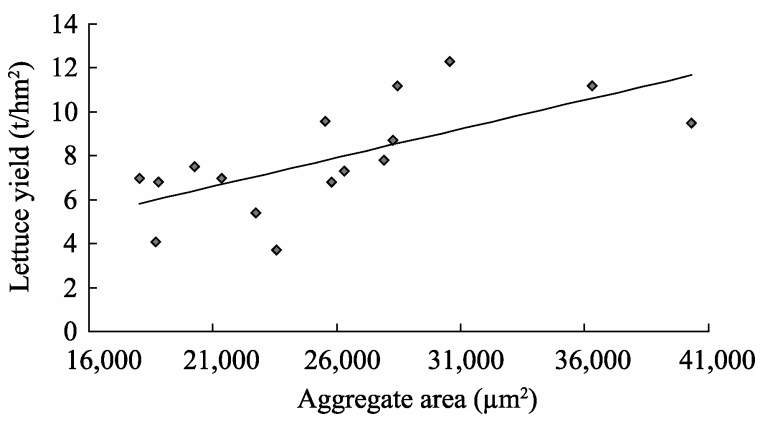

Fig. 5 Lettuce production as a function of aggregate area. The aggregate was measured in the micrographs using image analysis

Pore roughness is related to a combination of different factors difficult to evaluate independently in a field experiment. As expected, roughness was negatively correlated with $\mathrm{K}_{\text {sat }}$ (Table 1 ). The availability of water or anaerobic conditions may have a role in microbial activity and the accessibility of micronutrients. This may explain the negative correlation between roughness and yield of the more deeply rooted melon crop (Table 1).

Total melon production was not affected by soil compaction in this experiment, but marketable melon production was very sensitive to bulk density, total carbon, and total porosity (Table 1). This relationship can be understood through changes in $\Delta_{\mathrm{B}}$. Cantaloupe root development was positively affected by the better-developed soil structure (higher porosity, less $\Delta_{\mathrm{B}}$ ), increased total carbon content, and possibly the higher availability of water since soil water retention increased when porosity increased. Root development or productivity of lettuce was less affected by bulk density than were cantaloupes. The differential response to bulk density may be due to differences in the growth habit of the two crops - melons are deeper rooted, grow in hot weather, take longer to mature, and have a 
sharp rise in need for nutrients and water when they begin to set fruit. Lettuce is a shallow rooted cool season crop that is harvested well before becoming reproductive.

\section{Conclusions}

Increases in the colloidal fraction of the soils promoted increases in total carbon content. The total carbon, both inorganic and organic, was consistently below $1 \%$; even at such a low $\mathrm{C}$ concentration, however, we were able to use EM to quantify the cementing effect that $\mathrm{C}$ had on the soil colloidal particles. Micro-features of the soil structure, such as pore roughness and aggregate area, affected crop production; this effect varied with crop species marketable and total crop yield. The quality of lettuce and melons was negatively affected by pore roughness, and marketable melon yield was very sensitive to bulk density.

More studies are needed to identify the critical soil structure parameters affecting crop production. Quantification of how microbiological activity af-

\section{References}

Ajwa H A, Tabatabai M A. 1994. Decomposition of different organic materials in soils. Biology and Fertility of Soils, 18: 175-182.

Astier M, Gersper P L, Buchanan M. 1994. Combining legumes and compost: a viable alternative for farmers in conversion to organic agriculture. Compost Science \& Utilization, 2: 80-87.

Bartoli F, Philippy R, Burtin G. 1988. Aggregation in soils with small amounts of swelling clays. 1. Aggregate stability. Journal of Soil Science, 39: 593-616

Batte M T, Forster D L, Hitzhusen F J. 1993. Organic agriculture in Ohio: an economic perspective. Journal of production agriculture, 6 : $536-542$.

Bronick C J, Lal R. 2005. Soil structure and management: a review. Geoderma, 124: 3-22.

Chaney K, Swift R S. 1984. The influence of organic matter on aggregate stability in some British soils. Journal of Soil Science, 35: 223-230.

Cambardella C A, Elliot E T. 1993. Carbon and nitrogen distribution in aggregates from cultivated and native grassland soils. Soil Biology and Biochemistry, 57: 1071-1076.

Chenu C. 1993. Clay- or sand-polysaccharide associations as models for the interface between micro-organisms and soil: water related properties and microstructure. Geoderma, 56: 143-156.

Cuevas G, Blazquez R, Martinez F, et al. 2000. Composted MSW ef- fects organic matter degradation, soil structure, and feedback processes will give us a better understanding of the complex interactions of the soil matrix with both microbial population and microbial diversity. Incorporation of organic amendments can increase the short-term carbon content in the soil (Ajwa and Tabatabai, 1994), but the effects of organic amendments on the long-term accumulation of soil carbon are uncertain. Long-term accumulated C (i.e. recalcitrant $\mathrm{C}$ ) has mean residence times in soils of 500 to 3,000 years (Oades, 1989; Stevenson, 1994), while fresh material may decompose to insignificant levels in a few weeks (Ajwa and Tabatabai, 1994). Thus the long-term accumulation of $\mathrm{C}$ in soils depends in part on whether the management system encourages or discourages the formation of highly recalcitrant clay-humic complexes (Laird, 2001), which partly determines the sustainability of the system.

\section{Acknowledgements}

We thank Scott LESCH for the statistical analysis.

fects on soil properties and native vegetation in a degraded semiarid shrubland. Compost Science \& Utilization, 8: 303-309.

Dorioz J M, Robert M, Chenu C. 1993. The role of roots, fungi and bacteria on clay particle organization. An experimental approach. Geoderma, 56: 179-194.

Drinkwater L E, Letourneau D K, Workneh F, et al. 1995. Fundamental differences between conventional and organic tomato agroecosystems in California. Ecological Applications, 5: 1098-1112.

Elliot E T. 1986. Aggregate structure and carbon nitrogen and phosphorous in native and cultivated soils. Soil Science Society of America Journal, 50: 627-633.

Gaillard V, Chenu C, Recous S, et al. 1999. Carbon, nitrogen and microbial gradients induced by plant residues decomposing in soils. European Journal of Soil Science, 50: 567-578.

Gee G W, Bauder J W. 1986. Particle size analysis. In: Klute A. Methods of Soil Analysis. Part 1. Physical and Mineralogical Methods. $2^{\text {nd }}$ ed. Madison, WI: ASA and SSSA, 383-412.

Goldberg S, Forster H S. 1990. Flocculation of reference clays and arid-zone soil clays. Soil Science Society of America Journal, 54: 714-718.

Gregorich E G, Janzen H H. 2000. Microbially mediated processes. Decomposition. In: Malcolm E S. Handbook of Soil Science. Boca Raton, Fl: CRC Press. 
Gupta V V S R, Germida J J. 1988. Distribution of microbial biomass and its activity in different soil aggregate size classes as affected by cultivation. Soil Biology and Biochemistry, 20: 777-786.

Hesterberg D, Page A L. 1993. Critical coagulation concentration of sodium and potassium illite as affected by $\mathrm{pH}$. Soil Science Society of America Journal, 54: 735-739.

Hutchinson C M, McGiffen M E Jr. 2000. Cowpea cover crop mulch for weed control in desert pepper production. HortScience, 35: 196-198.

Juma N G. 1993. Interrelationships between soil structure/texture, soil biota/soil organic matter and crop production. Geoderma, 57: 3-30.

Kemper W D, Koch E J. 1966. Aggregate stability of soils from the western portions of the United States and Canada. USDA Tech. Bull. 1355. Washington DC: United States Government Printing Office.

Kretzschmar R, Robarge W P, Weed S B. 1993. Flocculation of kaolinitic soil clays: effects of humic substances and iron oxides. Soil Science Society of America Journal, 57: 1277-1283.

Laird D. 2001. Nature of clay-humic complexes in an agricultural soil: 11. Scanning electron microscopy analysis. Soil Science Society of America Journal, 65: 1419-1425.

Lebron I, Suarez D L. 1992. Variations in soil stability within and among soil types. Soil Science Society of America Journal, 56: 1412-1421.

Lebron I, Schaap M G, Suarez D L. 1999. Saturated hydraulic conductivity prediction from microscopic pore geometry measurements and neural network analysis. Water Resources Research, 35: 3149-3158.

Macrae R J, Mehuys G R. 1987. Effects of green maturing in rotation with corn on the physical properties of two Quebec [Canada] soils. Biological Agriculture \& Horticulture, 4: 257-270.

Magdoff F, Van Es H. 2000. Building Soils for Better Crops. $2^{\text {nd }}$ ed. Sustainable Agriculture Network, Handbook Series Book 4. Maryland: Beltsville, 230.

McGiffen M E Jr. 2011. Organic Vegetable Production Manual. California: University of California Agriculture and Natural Resources Communication Services, 99.

Merckx R, Den Hartog A, van Ven J A. 1985. Turnover of root-derived material and related microbial biomass formation in soils of different texture. Soil Biology and Biochemistry, 17: 565-569.

Oades J M. 1984. Soil organic matter and structural stability: mecha- nisms and implications for management. Plant and Soil, 76: 319-337.

Oades J M. 1987. Associations of colloidal materials in soils. In: XIII. Proceedings of the Congress of the International Society of Soil Science. Hamburg: 660-674.

Oades J M. 1989. An introduction to organic matter in mineral soils. In: Dixon J B, Weed S B. Minerals in Soil Environments. $2^{\text {nd }}$ ed. Madison, WI: SSSA, 89-159.

Oades J M. 1993. The role of biology in the formation, stabilization and degradation of soil structure. Geoderma, 56: 377-400.

Parr J F, Willson G B. 1980. Recycling organic wastes to increase soil productivity. HortScience, 15: 162-166.

Rhoades J D. 1982. Soluble salts. In: Page A L, Miller R H. Methods of Soil Analysis. Part 2. Chemical and Microbiological Properties. Madison, WI: ASA and SSSA, 167-178.

Roe N E. 1998. Municipal waste compost production and utilization for horticultural crops: introduction to the colloquium. HortScience, 33: 931.

Rutherford P M, Juma N G. 1992. Influence of soil texture on protozoa-induced mineralization of bacterial carbon and nitrogen. Canadian Journal of Soil Science, 72: 183-200.

SAS Institute Inc. 1988. SAS/STAT User's Guide, Release 6.03 ed. Cary, North Carolina: SAS Institute Inc.

Stevenson F J. 1994. Humus Chemistry. $2^{\text {nd }}$ ed. John New York: Wiley and Sons.

Tisdall J M, Oades J M. 1982. Organic matter and water stable aggregates in soils. Journal of Soil Science, 33: 141-163.

U.S. Salinity Laboratory Staff. 1954. Diagnosis and improvement of saline and alkali soils. In: USDA Agriculture Handbook. Washington DC: United States Government Printing Office, 60.

van Veen J A, Laad J N, Frissel M J. 1984. Modelling C and N turnover through the microbial biomass in soil. Plant and Soil, 76: 257-274.

van Veen J A, Liljeroth E, Lekkerkerk J A. 1991. Carbon fluxes in plant-soil system at elevated atmospheric $\mathrm{CO}_{2}$ levels. Ecological Society of America, 12: 175-181.

Wang G, Ngouajio M, McGiffen M E Jr, et al. 2008. Summer cover crop and management system affect lettuce and cantaloupe production system. Agronomy Journal, 100: 1587-1593.

Young I M, Ritz K. 1999. Tillage, habitat space and function of soil microbes. Soil and Tillage Research, 53: 201-213. 